\title{
Korozif Madde Alımı Nedeniyle Yatırılan 139 Olgunun Retrospektif Değerlendirilmesi: Epidemiyolojik Çalışma
}

\author{
Retrospective Analysis of 139 Cases Hospitalized due to Corrosive Ingestion: \\ An Epidemiological Study
}

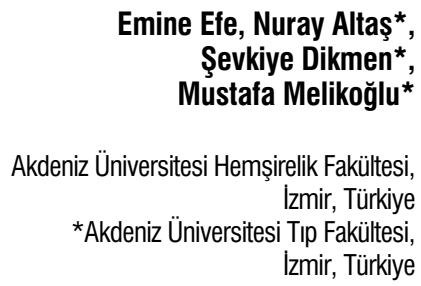

Yazışma Adresi/Address for Correspondence Emine Efe, Akdeniz Üniversitesi Hemşirelik Fakültesi, Izmir, Türkiye Tel.: +905337798302 E-posta: eefe@akdeniz.edu.tr

Geliş Tarihi/Received: 10.05.2013 Kabul Tarihi/Accepted: 13.09.2013

(c) Güncel Pediatri Dergisi, Galenos Yayınevi tarafindan basılmıştır.

(c) The Journal of Current Pediatrics, published by Galenos Publishing.

\section{ÖZET}

Giriş: Bu retrospektif çalışmayla korozif madde alımları ile ilgili ülkemiz epidemiyolojik veri tabanına katkıda bulunmayı amaçladık.

Gereç ve Yöntem: Akdeniz Üniversitesi Tıp Fakültesi Çocuk Cerrahisi Kliniği'ne 2005-2010 yılları arasında başvuran 139 korozif madde alımı olgusu geriye dönük olarak incelendi. Olgular yaş, cinsiyet, ailelerin sosyoekonomik düzeyleri, alınan etken madde ve yanık düzeyleri açısından değerlendirildi. Ayrıca çalışmadaki bazı veriler telefonla ulaşılabilen aileler ile görüşülerek dolduruldu.

Bulgular: Korozif madde alımının en sık görüldüğü yaş ortalamasının 3,35 $\pm 1,93$ olduğu ve çocukların çoğunluğunun erkek olduğu belirlendi. Annelerin yarıdan fazlasının ilkokul mezunu ve çalışmadığı saptandı. Kostik madde alımının en fazla yaz aylarında olduğu görüldü. Çocukların ilk sırada yağ çözücüleri aldıkları belirlendi. Çocukların annelerinin kostik maddeleri kapalı bir şekilde satın aldıkları, fakat evde bu maddeleri başka bir kaba böldükten sonra kullandıkları saptandı. Çocukların kostik maddeyi evlerinde içtiği ve ailelerin çocuklarını hiçbir uygulama yapmadan hastaneye getirdikleri belirlendi.

Sonuç: Çocuk sağlığının geliştirilmesi ve korunmasında önemli bir role sahip olan sağllk profesyonelleri; açıkta satılan ürünlerin alınmaması, bu ürünlerin içecek ve yiyecek kaplarına konmaması, uygun alanlarda ve kilitli olarak saklanması, korozif madde içilmesi durumunda çocukların kusturulmaması ve en yakın sağlık kuruluşuna başvurulması konusunda aileleri eğitmelidir. (Güncel Pediatri 2013; 11: 107-13)

Anahtar kelimeler: Epidemiyoloji, korozif madde alımı, çocuk, temizlik maddeleri

\section{SUMMARY}

Introduction: We aimed to contribute to the epidemiological database of our country with regard to corrosive material ingestions.

Materials and Methods: We retrospectively analyzed 139 cases of corrosive ingestion who were admitted to Pediatric Surgery Department of Akdeniz University between 2005 and 2010. Cases were evaluated in terms of age, gender, socioeconomic level, the active substance and levels of the burn. In addition some of the data were obtained by phone contacts with the families.

Results: The mean age of the most frequent intake of corrosive was $3.35 \pm 1.93$. It was determined that most of the children were male. More than half of the mothers were primary school graduates and working. It was found that caustic substance intake was found to be most frequent in summer months. It was also determined that children took ether phosphate most frequently and that mothers of children purchased caustic substances in a closed container, but these substances were divided to another utensil at home. It was found that children ingested caustic substances found in their homes and families were brought their children to the hospital without doing anything.

Conclusions: The increasing diversity of corrosive substances used in household cleaning, constitutes a great danger for children. In this respect, especially families at risk groups should be identified and these families need to be informed about the dangers of corrosive materials. (Journal of Current Pediatrics 2013; 11: 107-13)

Key words: Epidemiology, corrosive ingestion, children, household cleaners 


\section{Giriş}

Korozif maddelerin yanlışlıkla içilmesi, çocukluk çağında sık olarak karşımıza çıkan ve bazen ciddi komplikasyonlarla seyreden bir durumdur.

Amerika Birleşik Devletleri'nde her yıl yüz binden fazla çocukta korozif madde alımı görülmektedir (1). Türkiye'de yapılan çalışmalarda çocuk zehirlenmelerinin \%3,328,1'inin korozif madde alımına bağlı olduğu saptanmıştır (2-6). Amerikan Zehir Kontrol Merkezi Birliği 2008 raporuna göre; 5 yaş altındaki çocuklarda ev temizlik maddelerini içenlerin oranını \%9,7 (124.934 kiși) olarak bildirmektedir (7). Türkiye'de ise kayıtların sağlıklı olmaması nedeniyle sıklık tam olarak bilinmemektedir (8). Ancak yapılan bazı araștırmalarda ev temizlik ürünlerinin çocuk zehirlenme etkenleri arasında ilk sıralarda yer aldığı (9) ve yaș grubu bakımından çocukların 6 yaş altında, sıklıkla 3 yaş altı ve erkek çocuklar olduğu belirtilmektedir $(10,11)$. Çocuklarda korozif madde alımları genellikle kaza ile alım sonucu gerçekleşmekte, çocukların maruz kaldığı ev kazaları arasında da tıbbi, ekonomik ve sosyal yönlerden önem taşımaktadır $(10,12)$.

Akut zehirlenme nedenleri coğrafi bölge, mevsim ve sosyokültürel düzeye bağlıdır. Zehirlenmelere ait epidemiyolojik ve klinik özelliklerin belirlenmesi ile koruyucu önlemlerin sağlanması mümkün olabilir. Akdeniz Üniversitesi Hastanesi, yaklaşık 2.043.482 nüfusa hitap eden bir ilde 3. basamak bir tedavi merkezidir (13). Antalya ili ve çevresinde meydana gelen korozif madde içimi vakaları Akdeniz Üniversitesi Hastanesi'ne sevk edilmektedir.

Çalışmanın amacı, Antalya'daki bir eğitim ve araştırma hastanesine korozif madde içilmesi nedeniyle getirilen çocukların ve ailelerin özelliklerini, ailelerin korozif maddeleri satın alma ve saklama şeklini, çocukların içtikleri korozif maddeleri, ailelerin korozif madde alımı sonrası yaptığı ilk uygulamaları ve özofagusta meydana gelen yanık durumunu belirlemektir.

\section{Gereç ve Yöntemler}

Ocak 2005 - Aralık 2010 tarihleri arasında Akdeniz Üniversitesi Hastanesi'nde korozif madde içimi nedeni ile yatırılarak tedavi edilen 139 çocuğun dosyaları retrospektif olarak incelendi. Ayrıca çalışmadaki bazı veriler (ebeveynlerin eğitimi, mesleği, aile yapısı, gelir durumu, çalışma durumu, kardeş sayısı ve yaşı, sosyoekonomik durum, içilen korozif maddenin satın alınma ve saklanma şekli, içildiği mevsim, içilen yer) telefonla ulaşılabilen aileler ile görüşülerek toplandı. Çalıșmadaki toplam 139 korozif madde alımı olgusunun 106'sının aileleri ile telefon görüşmesi yapılabildi.

Veriler toplanmadan önce Akdeniz Üniversitesi Hastanesi Başhekimliği'nden ve Çocuk Cerrahisi Anabilim Dalı Başkanlığı'ndan gerekli yasal izinler alındı.
Verilerin analizi SPSS 20.0 programında analiz edildi. Verilerin değerlendirilmesinde tanımlayıcı istatistiksel metotlar (frekans, yüzdelik, ortalama, standart sapma) kullanıldı.

\section{Bulgular}

Çalışmanın kapsadığı 5 yıllık (2005-2009) dönemde, Akdeniz Üniversitesi Hastanesi Çocuk Cerrahisi Servisine korozif madde içimi nedeniyle başvuran 139 hastanın verileri değerlendirildi.

Çocukların yaş ortalamaları 3,35 $\pm 1,93$ (dağılım, 1-8 yaş) olarak bulundu. Çocukların 78 'i $(\% 56,1)$ erkek, 61'i $(\% 43,9)$ kIz olarak belirlendi. Annelerin \%51,8'inin ilkokul mezunu ve $\% 57,6$ 'sının çalışmadığı saptandı. Ailelerin $\% 38,1$ 'inin gelir durumunun giderlerine eşit olduğu belirlendi. Çocukların \%61,9'unun çekirdek aile yapısına sahip olduğu ve ailenin ikinci çocuğu $(\% 45,3)$ olduğu saptandı. Ailelerin \%51,1'inin il merkezinde yaşadığı belirlendi (Tablo 1).

Korozif madde alımının en fazla yaz aylarında $(\% 33,8)$ (Şekil 1) ve Temmuz ayında (\%15,8) olduğu görüldü (Tablo 2). Çocukların içtikleri korozif madde çeşitleri arasında ilk sırayı yağ çözücü $(\% 36,0)$, ikinci sırayı ise porçöz $(\% 24,5)$ ürünlerinin aldığı belirlendi. Çocukların \%61,9'unun korozif maddeyi evlerinde içtiği saptandı. Annelerin \%62,6'sının içilen korozif maddeyi kapalı bir şekilde satın aldığı belirlendi. Ayrıca annelerin \%46,8'inin satın aldıkları maddeyi evde başka bir kapta (pet şişe, bardak, kavanoz, poşet) sakladıkları saptandı. Cocukların \%72,7'sinin korozif madde alımından sonraki ilk 30 dakika içinde sağlık kuruluşuna getirildiği belirlendi. Ailelerin \%23,0'ının korozif madde içen çocuklarına hiçbir uygulama yapmadan sağlık kuruluşuna getirdikleri, \%21,6'sının çocuğun ağzını su ile çalkaladığı belirlendi (Tablo 3).

Korozif madde içen çocukların fiziki bulgularına bakıldığında, \%38,8'inde ağız içinde ve çevresinde kızarıklık, \% 33,1'inde ise orofarenkste hiperemi olduğu saptandı (Tablo 4).

Korozif madde içen çocukların endoskopi bulguları incelendiğinde, \%18'inde 1. derece, \%15,8'inde 2. derece ve \%18'inde 3. derece yanık olduğu görülmüștür (Şekil 2).

Korozif madde içen çocukların yıllara göre dağlımına bakıldığında, 2009 yılında sayıda önemli bir artış olduğu $(n=43)$ belirlendi (Şekil 3).

\section{Tartışma}

Amerika Birleşik Devletleri'nde altı yaş altındaki çocuklarda zehirlenmeye neden olan maddelerin başında kozmetik ve kişisel bakım ürünleri $(\% 13,4)$, ikinci sırada ise korozif maddeler $(\% 9,7)$ gelmektedir (14). Ülkemizde zehirlenme etkenleri içinde genel olarak ilk sırada ilaçlar yer almasına karşın, 2000'li yıllardan itibaren yapılan bazı 
çalışmalarda korozif maddelerin birinci sırada $(15,16)$, bazılarında ise ikinci sırada olduğu görülmektedir (4$6,17,18)$.

Çalışmamızda, hastaneye korozif madde alımı nedeniyle getirilen çocukların cinsiyetlerinin yarısından fazlasının erkek ve yaş ortalamalarının 3,35 $\pm 1,93$ olduğu belirlendi.

\begin{tabular}{|c|c|c|}
\hline Özellikler & n & $\%$ \\
\hline \multicolumn{3}{|l|}{ Çocuğun cinsiyeti } \\
\hline KIz & 61 & 43,9 \\
\hline Erkek & 78 & 56,1 \\
\hline \multicolumn{3}{|l|}{ Anne eğitimi } \\
\hline llköğretim & 72 & 51,8 \\
\hline Lise ve üzeri & 34 & 24,5 \\
\hline Bilinmeyen & 33 & 23,7 \\
\hline \multicolumn{3}{|l|}{ Annenin çalışma durumu } \\
\hline Çalışıyor & 26 & 18,7 \\
\hline Çalışmıyor & 80 & 57,6 \\
\hline Bilinmeyen & 33 & 23,7 \\
\hline \multicolumn{3}{|l|}{ Ekonomik durum } \\
\hline Gelir giderlerine eşit & 53 & 38,1 \\
\hline Gelir giderlerinden az & 43 & 30,9 \\
\hline Gelir giderlerinden fazla & 8 & 5,8 \\
\hline Bilinmeyen & 35 & 25,2 \\
\hline \multicolumn{3}{|l|}{ Aile Yapısı } \\
\hline Çekirdek aile & 86 & 61,9 \\
\hline Geniş aile & 18 & 12,9 \\
\hline Anne baba ayrı & 1 & 0,7 \\
\hline Bilinmeyen & 34 & 24,5 \\
\hline \multicolumn{3}{|l|}{ Kaçıncı çocuk } \\
\hline 1. & 52 & 37,4 \\
\hline 2. & 63 & 45,3 \\
\hline 3. & 16 & 11,5 \\
\hline 4. ve Üzeri & 6 & 4,3 \\
\hline Bilinmeyen & 2 & 1,4 \\
\hline \multicolumn{3}{|l|}{ Ailelerin yaşadığı yer } \\
\hline$\|$ & 71 & 51,1 \\
\hline Illçe & 55 & 39,6 \\
\hline Köy & 13 & 9,4 \\
\hline
\end{tabular}

Çalışmada korozif madde içiminin çoğunlukla erkek çocuklarda görülmesi literatürle benzerlik göstermektedir (19-21). Özellikle erkek çocuklarda madde içiminin daha çok görülmesinin nedeni bu cinsteki çocukların daha hareketli olmalarıdır. Literatürde korozif madde içiminin de yer aldığı zehirlenmelerin genellikle 6 yaş altında olduğu görülmektedir (4,5,10,19,21-24). Bizim araştırma sonucumuz bahsedilen araştırma sonuçları ile benzerlik göstermektedir.

Çalışmada korozif madde içen çocukların ebeveynlerinin eğitim düzeylerinin oldukça düşük olduğu ve annelerinin büyük çoğunluğunun bir iş sahibi olmadığı görülmüştür. Yapılan çalışmalarda da korozif madde içen çocukların ebeveynlerinin eğitim düzeylerinin oldukça düşük olduğu saptanmıştır $(10,11,19,25-$ 29). Bizim çalışma sonucumuz bahsedilen araştırma sonuçları ile benzerlik göstermektedir. Doruk ve ark., Kayaalp ve ark., Karaman ve ark. çalışmalarında anne eğitimi ile özofagus yanığı oluşumu arasında anlamlı bir ilişki olduğunu bulmuşlardır $(10,19,29)$. Bizim çalışma sonucumuz Doruk ve ark., Kayaalp ve ark., Karaman ve ark. çalışma sonuçları ile benzerlik göstermemektedir. Bizim çalışmamızda ise, özofagus yanığı eğitim düzeyi hem yüksek hem de düşük olan annelerin çocuklarında görülmüştür.

Çalışmayan anneler evlerinde çocuklarına daha fazla zaman ayırabilirler. Oysaki çalışmamızda çalışmayan annelerin çocuklarında da özofagus yanığının olduğu görülmüştür. Bununla birlikte, araştırmamızdaki ailelerin yapısına bakıldığında çoğunluğunun çekirdek aile yapısında olduğu saptanmıştır. Bu sonuçlara göre, çalışmayan, eğitimli, az sayıda çocuğu olan annelerin çocukları ile ev ortamında yeteri kadar ilgilenmediklerini düşünebiliriz.

\begin{tabular}{|l|l|l|}
\hline \multicolumn{3}{|l|}{$\begin{array}{l}\text { Tablo 2. Çocukların korozif maddeleri içtikleri aylara göre } \\
\text { dağılımı }\end{array}$} \\
\hline Aylar & n & $\%$ \\
\hline Ocak & 3 & 2,2 \\
\hline Şubat & 10 & 7,2 \\
\hline Mart & 9 & 6,5 \\
\hline Nisan & 10 & 7,2 \\
\hline Mayıs & 12 & 8,6 \\
\hline Haziran & 10 & 7,2 \\
\hline Temmuz & 22 & 15,8 \\
\hline Ağustos & 15 & 10,8 \\
\hline Eylül & 15 & 10,8 \\
\hline Ekim & 14 & 10,1 \\
\hline Kasım & 11 & 7,9 \\
\hline Aralık & 8 & 5,8 \\
\hline
\end{tabular}




\begin{tabular}{|c|c|c|}
\hline Özellikler & $\mathrm{n}$ & $\%$ \\
\hline \multicolumn{3}{|l|}{ Içilen maddenin türü } \\
\hline Yağçöz & 50 & 36,0 \\
\hline Porçöz & 34 & 24,5 \\
\hline Diğer maddeler (lavabo açıcı, bulaşık makinası parlatııısı, & 55 & 39,6 \\
\hline \multirow{3}{*}{\multicolumn{3}{|c|}{$\begin{array}{l}\text { kirçöz, nitrik asit, çamaşır suyu, sirke, kosla, tuz ruhu, } \\
\text { cam sil, bulaşık makinası deterjanı, sönmüş kireç, fosforik } \\
\text { asit, leke çıkarıcı, oksijenli su, potasyum manganat) }\end{array}$}} \\
\hline & & \\
\hline & & \\
\hline \multicolumn{3}{|l|}{ Maddenin içildiği yer } \\
\hline Evde & 86 & 61,9 \\
\hline Misafirlikte & 24 & 17,3 \\
\hline Diğer (tarla, yurt, otel v.s.) & 14 & 10,1 \\
\hline Bilinmeyen & 15 & 10,8 \\
\hline \multicolumn{3}{|l|}{ Maddenin satın alma şekli } \\
\hline Kapalı & 87 & 62,6 \\
\hline Açık & 23 & 16,5 \\
\hline Bilinmeyen & 29 & 20,9 \\
\hline \multicolumn{3}{|l|}{ Maddenin saklanma şekli } \\
\hline Başka bir kapta (pet şişe, bardak, kavanoz, poşet) & 65 & 46,8 \\
\hline Kendi orijinal kabında & 51 & 36,7 \\
\hline Bilinmeyen & 23 & 16,5 \\
\hline \multicolumn{3}{|l|}{ Maddenin evde saklanma yeri } \\
\hline Mutfak & 21 & 15,1 \\
\hline Banyo & 27 & 19,4 \\
\hline Dolap & 28 & 20,1 \\
\hline Diğer & 29 & 20,9 \\
\hline Bilinmiyor & 34 & 24,5 \\
\hline \multicolumn{3}{|l|}{ Çocuğun sağlık kuruluşuna getirilme zamanı (dakika) } \\
\hline $0-30 \mathrm{dk}$ & 101 & 72,7 \\
\hline $31-60 \mathrm{dk}$ & 12 & 8,6 \\
\hline $61-90 \mathrm{dk}$ & 3 & 2,2 \\
\hline $91-120 \mathrm{dk}$ & 3 & 2,2 \\
\hline 121 ve üzeri dk & 3 & 2,2 \\
\hline Bilinmiyor & 17 & 12,2 \\
\hline \multicolumn{3}{|c|}{ Ailenin korozif madde içiminden sonra çocuklara yaptığı ilk uygulamalar } \\
\hline Bir şey yapmadan sağllk kuruluşuna getirme & 32 & 23,0 \\
\hline Ağzını su ile çalkalama & 30 & 21,6 \\
\hline Su içirme & 23 & 16,5 \\
\hline Kusturma & 23 & 16,5 \\
\hline Süt içirme & 21 & 15,1 \\
\hline Bilinmeyen & 10 & 7,2 \\
\hline
\end{tabular}


Çam ve arkadaşları çalışmalarında, temizlik maddeleriyle olan zehirlenmelerin en sık yaz ve kış mevsimlerinde görüldüğünü belirtmișlerdir (4). Eskișehir Osmangazi Üniversitesi'nde yapılan bir çalışmada, korozif madde alımlarının \%37'sinin yaz mevsiminde meydana geldiği saptanmıştır (5). Biçer ve ark. çalışmalarında, korozif madde alımlarının çoğunlukla Ağustos ayında ve yaz mevsiminde olduğunu bildirmişlerdir (30). Bizim çalışmamızda ise, Temmuz ayında ve yaz mevsiminde olduğu saptanmıştır. Çalışma sonucumuz diğer çalışma sonuçları ile benzerlik göstermektedir. Korozif madde alımının yaz mevsiminde ve Temmuz ayında görülmesinin

\begin{tabular}{|l|l|l|}
\hline Tablo 4. Korozif madde içen çocuğun fiziki bulguları \\
\hline Fiziki Bulgular & n & $\%$ \\
\hline Normal & 32 & 23,1 \\
Ağız içinde ve çevresinde kızarıklık & 54 & 38,8 \\
Ağızdan salya ve tükürük gelmesi & 7 & 5 \\
Orofarenkste hiperemi & 46 & 33,1 \\
\hline
\end{tabular}

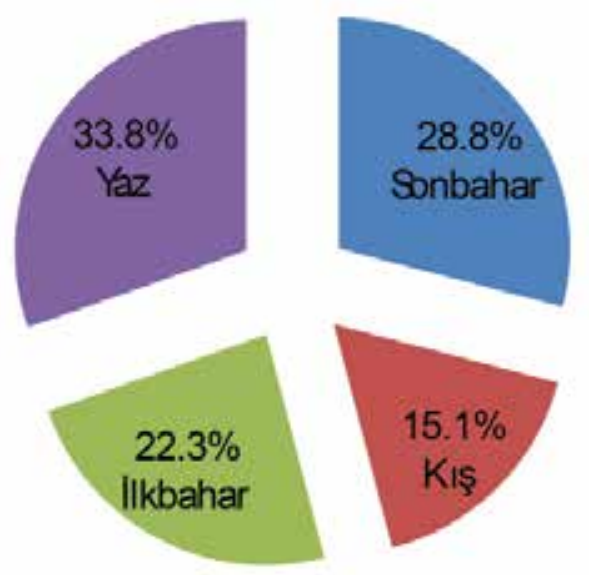

Şekil 1. Içilen korozif maddelerin mevsimlere göre dağııımı

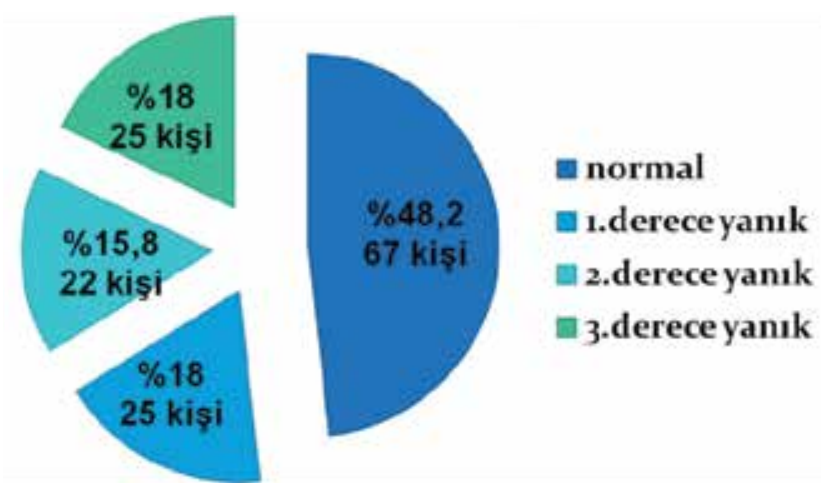

Şekil 2. Korozif madde içen hastaların endoskopi bulguları nedeni, annelerin kış mevsimine girmeden önce evlerinde büyük bir temizlik yapmaları olabilir. Araştırmamızda annelerin \%46,8'inin temizlik malzemelerini başka bir kapta (su şişesinde \%19,4, bardakta 51,8, gazoz şişesinde $\% 5,8$ ) sakladıkları saptanmıştır. Anneler evlerinde yaptıkları temizlik sırasında kullandıkları temizlik malzemelerini ortada bırakmış olabilirler. Ayrıca bu mevsimlerde aşırı sıcaklardan dolayı, günlük su alım miktarı artmaktadır. Çocuklar daha fazla susadıkları için ortalıkta bulunan, su gibi görünen her türlü sıvıyı (temizlik malzemesini) içmiş olabilirler.

Çalıșmamızda, hastaneye korozif madde alımı nedeniyle getirilen çocukların en sık içtiği korozif maddenin yağ çözücü olduğu saptanmıştır. Bizim çalışma sonucumuz Ekinci ve ark., Kayalp ve ark., Biçer ve arkadaşlarının çalışma sonuçları benzerlik göstermektedir $(10,30,31)$. Çalışmamızda, yağ çözücülerinin en sık alınan korozif madde olarak karşımıza çıkmasının nedeni, Türkiye'de yağ çözücülerin üretiminin ve ev temizliğinde kullanımlarının yaygınlaşması olabilir.

Çalışmamızda, çocukların yarısından fazlasının korozif maddeyi evlerinde içtikleri belirlendi. Küçük ve Balcı, Kayaalp ve ark., Conk ve ark., Riffat ve Cheng çalışma sonuçları bizim sonucumuzla benzerlik göstermektedir. Özellikle küçük çocukların yaşam alanlarının çoğunlukla ev ortamında olması, bu tür zehirlenmelerin evde sık görülmesine neden olmaktadır. Ülkemizde, çocukların çoğunluğu kreşe gitmemektedir. Ev ortamında aynı zamanda çocuklar için oyun alanıdır. Çocuklar evde buldukları her şeyi oyunlarında kullanabilirler. Bu durum korozif madde alımı riskini artırabilir.

Çalışmamızda temizlik maddelerinin satın alma şekli incelendiğinde; annelerin \%62,6'sının maddeyi kapalı yani orijinal kabında aldığı, fakat annelerin kapalı aldıkları maddeleri başka bir kapta (pet şişe, bardak, kavanoz, poşet) sakladıkları saptanmıştır. Küçük ve Balcı çalışmalarında benzer sonucu bulmuşlardır (28). Conk ve ark., Kayaalp ve ark. annelerin temizlik maddelerini açık olarak satın aldıklarını saptamışlardır $(10,22)$. Çalışmamızda temizlik

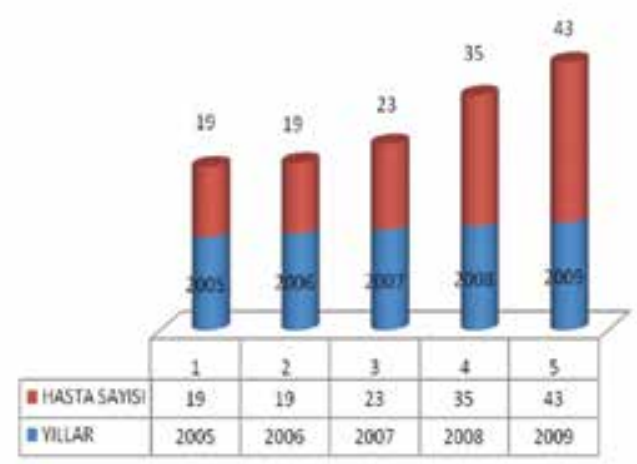

Şekil 3. Korozif madde içen hastaların yıllara göre dağılımı 
maddelerinin açık alınma oranı diğer araştırmaların sonuçlarına göre daha düşük bulunmuştur. Çalışmamızda ailelerin ekonomik durumunun çoğunluğunun gelirlerinin giderlerine eşit olmasından ve ailelerin biraz daha bu konuda bilinçlenmiş olması, temizlik maddelerinin kapalı şekilde alımını artırmış olabilir.

Çalışmamızda, ailenin korozif madde içtikten sonra çocuklara yaptığı ilk uygulamaların çocuğa hiçbir şey yapmadan sağlık kuruluşuna götürme ve çocuğun ağzını su ile çalkalama olduğu belirlendi. Küçük ve Balcı ailelerin çoğunluğunun çocuklarına ilk uygulama olarak su, süt ve yoğurt verdiklerini, Buke ve ark. çocuğu kusturduğunu ya da onlara limon suyu, yoğurt, ayran, zeytinyağı, vb. yiyecekleri verdiklerini, Tosyalı ve ark., ailelerin çocuğu kusturduğunu bildirmişlerdir $(27,28,32)$. Conk ve ark., ailelerin büyük bölümünün çocuğa hiçbir şey yapmadan hastaneye getirdiğini saptamışlardır (22). Çalışma sonucumuz Küçük ve Balcı, Buke ve ark., Tosyalı ve ark. çalışma sonuçları ile benzerlik göstermezken, Conk ve ark. çalışma sonuçları ile benzerlik göstermektedir $(27,28,32)$. Korozif madde içen çocuklara soğuk su, süt veya ayran içirilmesinin bu maddeleri özofagus mukozasından uzaklaştıracağı ve daha dayanıklı olan midede seyreltik Sıvı durumuna getireceği için, sınırlı da olsa bazı kaynaklarda verilebileceği belirtilmektedir (33-35). Bununla birlikte, korozif madde içiminden sonra başka bir yiyecek/ içeceğin verilmesi total gastrik volümü arttırıp kusmayı uyarabileceğinden, ağızdan hiçbir şey verilmemesinin daha uygun olduğu bildirilmektedir. Çünkü maddeyi yutarken zedelenen özofagus ve larinks, kusma ile yeniden zarara uğrayacaktır. Bu yüzden çocukların hiçbir şey yapmadan en kısa süre içinde hastaneye getirilmelerinin daha uygun olduğu belirtilmektedir (36). Çalışmamızdaki ailelerin çoğunluğunun korozif madde alımından hemen sonra çocuklarını sağlık kuruluşuna götürmelerinin doğru bir davranış olduğu görülmektedir.

Çalışmamızda korozif madde içen çocukların fiziki inceleme bulgularına bakıldığında çoğunluğunun ağız içi ve çevresinde kızarıklık olduğu görülmüştür. Akbay ve Uçar, Öner ve ark., Biçer ve arkadaşlarının çalışmalarında, çocuklarda ağız mukozasında hiperemi ve ödemin en sık görülen fiziksel bulgu olduğunu bildirmişlerdir $(5,6,12)$. Bizim sonuçlarımız bahsedilen çalışma sonuçları ile benzerlik göstermektedir.

Çalışmaya alınan olguların özofagoskopi sonuçları incelendiğinde yarısından fazlasında (\%18 1.derece, \%15,8 ikinci derece, \%18 üçüncü derece) yanık olduğu görülmüştür (Şekil 2). Literatürde incelenen araştırmaların sonuçları, yanık dereceleri arasında önemli farklııklar olduğunu göstermektedir (36-38). Ekinci ve ark. çalışmasında, özofagus darlığı gelişen hastalarda, en sık içilen maddenin yağ çözücü olduğu ortaya konmuştur (31). Cankorkmaz ve ark., Doruk ve ark. çalışmalarında özofagusta en çok yanık oluşturan korozif maddenin yağ çözücü olduğunu bildirmişlerdir $(19,33)$. Bu sonuç, yağ çözücülerin içerdikleri sodyum hidroksitin yüksek korozif etkisinden kaynaklanmaktadır. Yağ çözücülerin ev temizliğinde kullanımları yanlışlıkla içilmelerini yaygınlaştırmıştır. Özofagus yanık derecelerinin bu kadar farklı olmasının nedeni, içilen madde ve alınan miktar ile ilişkili olduğu gibi, aynı zamanda imalat aşamalarında belli bir standardın olmaması da olabilir. Çalışmamızda yağ çözücülerin içilme oranının yüksek bulunmasına rağmen, içilen korozif etkenler ile özofagus yanık oluşumu arasında anlamlı bir fark olmadığı bulunmuştur ( $p>0,05)$.

Çalışmamızda korozif madde içen hastaların yıllara göre dağılımında artış olduğu saptanmıştır. Korozif madde içimindeki bu artışın nedeni; her evde korozif madde içeren ürünlerin bulunması, kapalı olarak büyük kaplarda aldıkları temizlik ürünlerini kullanımlarını kolaylaştırmak için küçük kaplara boşaltmaları, çocukların kendi orijinal kaplarında olmayan bu tür ürünleri yanlışsıkla besin maddesi ya da su olduğunu düşünerek içmeleri olabilir.

Sonuç olarak, ev temizliğinde kullanılan korozif maddelerin çeşidinin ve korozif etkilerinin her geçen gün artması, çocuklar için büyük tehlike oluşturmaktadır. Çocuk sağığının geliștirilmesi ve korunmasında önemli bir role sahip olan sağlık profesyonelleri, açıkta satılan ürünlerin alınmaması, bu ürünlerin içecek ve yiyecek kaplarına konmaması, uygun alanlarda ve kilitli olarak saklanması, korozif madde içilmesi durumunda çocukların kusturulmaması ve en yakın sağlık kuruluşuna başvurulması konusunda aileleri eğitmelidir (21).

\section{Kaynaklar}

1. Litovitz TL, Schmitz BF, Bailey KM. 1989 annual report of the American Association of Poison Control Centers National Data Collection System. Am J Emerg Med 1990;8:394-442.

2. Yafet-Aji D, Keskin S, Ilter Ö. I Ü Cerrahpaşa Tip Fakültesi Çocuk Sağlı̆ı ve Hastalıkları Anabilim Dalı, Acil biriminde izlenen zehirlenmelerin değerlendirilmesi. Türk Pediatri Arşivi 1998;33:148-53.

3. Aydınoğlu $H$, Aygün $A D$, Güngör $S$, Turgut $M$, Doğan Y. Firat Üniversitesi Tıp Fakültesinde izlenen 176 çocuk zehirlenme olgusunun değerlendirilmesi. Türk Pediatri Arşivi 2000;35:245-8.

4. Çam H, Kıray E, Taştan Y, Özkan HÇ. Istanbul Üniversitesi Cerrahpaşa Tıp Fakültesi Çocuk Sağlığı ve Hastalıkları Anabilim Dalı Acil servisinde izlenen zehirlenme olguları. Türk Pediatri Arşivi 2003;38:233-9.

5. Akbay-Öntürk Y, Uçar B. Eskişehir Bölgesinde çocukluk çağı zehirlenmelerinin retrospektif değerlendirilmesi. Çocuk Sağlı̆ı ve Hastallkları Dergisi 2003;46:103-13.

6. Öner N, Inan M, VatanseverÜ, Turan Ç, Çeltik C, Küçükuğurluoğlu Y, ve ark. Trakya bölgesinde çocuklarda görülen zehirlenmeler. Türk Pediatri Arşivi 2004;39:25-30.

7. American Association of Poison Control Centers, www.aapcc. org 
8. Kutlu T. Kostik Madde Alan Çocuğa Yaklaşım. 32. Pediatri Günleri ve 11. Pediatri Hemşireliği Günleri Özet Kitabı. Istanbul: 2010.

9. Andıran N, Sarıkayalar F. Pattern of Acute Poisonings in Childhood in Ankara: What Has Changed in Twenty Years? Turk J Pediatr 2004;46:147-52.

10. Kayaalp L, Odabaşı G, Doğangün B, Çavuşoğlu P, Bolat N, Bakan M, ve ark. Endoskopik izlem gerektiren korozif yanıkları olan çocuk ve ergenlerde kazanın meydana geliş şekli ve aile özelliklerinin değerlendirilmesi. Türk Pediatri Arşivi 2006;41:24-30.

11. Penbegül ML. Ilaç zehirlenmesi olan çocuk olgularda demografik özellikler ve ailesel etkenlerin değerlendirilmesi. Uzmanlık Tezi, Haydarpaşa Numune Eğitim ve Araştırma Hastanesi. Istanbul 2006.

12. Yeker D. Kostik özofagus yanıkları. Içinde: Çocuk Cerrahisi Pediatric Surgery. Istanbul: Avrupa Tıp Kitapçılık Ltd. 2005:277284.

13. Türkiye Istatistik Kurumu 2012. www.tuik.gov.tr/IcerikGetir. do?istab_id $=139$

14. Watson WA, Litovitz TL, Klein-Schwartz W, Rodgers GC Jr, Youniss J, Reid N, et al. 2003 Annual Report of the American Association of Poison Control Centers Toxic Exposure Surveillance System. Am J Emerg Med 2004;22:335-404.

15. Yılmaz A, Biçer S, Sezer S, Gülcan M, Aydoğan, Aldemir H. Çocukluk çağı zehirlenme olgularının epidemiyolojik ve klinik özelliklerinin incelenmesi. Jinekoloji Obstetrik Pediatri Dergisi 2005;11:148-54.

16. Akçay A, Gürses D, Özdemir A, Kılıç I, Ergin H. Denizli ilindeki çocukluk çağı zehirlenmeleri. Adnan Menderes Üniversitesi Tıp Fakültesi Dergisi 2005;6:15-9.

17. Arapoğlu M, Keskin C, Telhan L, Erdem E, Palanduz A. Şişli Etfal Hastanesi 1. çocuk kliniğine başvuran zehirlenme olgularının değerlendirilmesi. Şişli Etfal Hastanesi Tıp Bülteni 2005;4:415.

18. Soyucen E, Aktan Y, Saral A, Akgün N, Numanoğlu AÜ. Sakarya Bölgesinde çocukluk çağı zehirlenmelerinin zeriye dönük olarak değerlendirilmesi. Çocuk Sağlığı ve Hastalıkları Dergisi 2006;49:301-6.

19. Doruk D, Narcı A, Korkmaz M, Koltuksuz U, Özkaraca E. Korozif madde cinsinin ve hasta yaşının özofagus yanığı derecesi üzerine etkisi. Kocatepe Tıp Dergisi 2007;8:9-14.

20. Karaarslan B, Turla A, Aydın B. Ondokuz Mayıs Üniversitesi Tıp Fakültesi Acil Servisine Başvuran Korozif Madde Zehirlenmeleri. Van Tip Dergisi 2007;14:109-13.

21. Kondolot M, Akyıldız B, Görözen F, Kurtoğlu S, Patıroğlu T. Çocuk Acil Servisine Getirilen Zehirlenme Olgularının Değerlendirilmesi. Çocuk Sağığı ve Hastalıkları Dergisi 2009;52:68-74.

22. Conk Z, Bal Yılmaz H, Şen D, Erdoğdu M. Korozif madde içen çocukların değerlendirilmesi ve ailelerinin hastaneye başvurana kadar uyguladıkları yöntemlerin saptanması. Ege Üniversitesi Hemşirelik Yüksekokulu Dergisi 2004;20:1-9.
23. Kahveci M, Çeltik C, Karasalihoğlu S, Acunaş B. Bir üniversite hastanesi acil servisine başvuran çocukluk çağı zehirlenmelerinin geriye dönük değerlendirilmesi. Sted 2004;13:19-21.

24. Koturoğlu G, Kurugöl Z, Yiğit M, Solak I. Ege Üniversitesi Tıp Fakültesi Çocuk Acil ünitesine zehirlenme nedeni İle başvuran olguların değerlendirilmesi. Ege Pediatri Bülteni 2005;12:161-5.

25. Güven A. Çocukları Evde bekleyen tehlike: Korozif özofagus yanıkları. TAF Prev Med Bull 2008;7:535-40.

26. Ceylan Ö. Korozif madde içen süt çocuklarında sosyal, demografik ve endoskopik bulguların değerlendirilmesi. Şişli Etfal Eğitim ve Araştırma Hastanesi, Yayınlanmamış Uzmanlık Tezi. Istanbul 2008.

27. Buke SA, Corduk N, Atesci F, Karabul M, Koltuksuz U. A different aspect of corrosive ingestion in children: socio-demographic characteristics and affect of family functioning. Int J Pediatr Otorhinolaryngol 2006;70:1791-8.

28. Küçük F, Balcı S. Korozif madde içen 1-6 yaş grubu çocukların özellikleri ve ailelerin yaptığı ilk uygulamalar. Anadolu Hemşirelik ve Sağlık Bilimleri Dergisi 2011;14:33-9.

29. Riffat F, Cheng A. Pediatric Caustic Ingestion: 50 Consecutive Cases and A Review of The Literature. Dis Esophagus 2009;22:89-94.

30. Biçer S, Gülcan EM, Yeşinel S, Yıldırım S, Şengül A, Aydoğan G. Kostik madde alan çocukların analizi. Bozok Tıp Dergisi 2011;1:1-10.

31. Ekinci S, Tanyel FC, Şenocak ME, Büyükpamukcu N. Ülkemizde çocukluk çağı korozif striktürlerinin güncel nedenleri ve önlem önerileri. Çocuk Cerrahisi Dergisi 2004;18:118-23.

32. Tosyalı AN, Mutuş HM, Ulukaya Durakbaşa Ç, Sert M, Şehiraltı Ö, ve ark. Kostik madde alımı öyküsü olan her bir çocukta rutin endoskopik inceleme yapılmalı mıdır?, XXVI. Ulusal Çocuk Cerrahisi Kongresi, XII. Ulusal Çocuk Cerrahisi Hemşireliği Kongresi Özel Sayısı 2008;22:164.

33. Cankorkmaz L, Köylüoğlu G, Güney C. Korozif özofagus yanıklı çocuklar ve özofagoskopi. Çocuk Cerrahisi Dergisi 2009;23:110-3.

34. Huang YC, Ni YH, Lai HS, Chang MH. Corrosive esophagitis in children. Pediatr Surg Int 2004;20:207-10.

35. Hockenberry MJ, Wilson D, Winkelstein ML. Wong's Essentials of Pediatric Nursing. 7 th ed. Philadelphia: Mosby Inc; 2005.

36. Kutlu T, Çullu F, Erkan T, Aji D, Tümay GT. Korozif madde içen çocukların değerlendirilmesi. Türk Pediatri Arşivi 1998;33:92-8.

37. Sözübir S. Kahraman H. Ekingen G. Korozif madde alan olgularda klinik sonuçlarımız, Çocuk Cerrahisi Kongresi 2004; Poster Bildiri-51.

38. Choi DH, Cho MG, Ju HG, Kim BJ, Ma JS. A clinical observation on children with corrosive esophagitis. Korean J Pediatr Gastroenterol Nutr 2000;3:1-8. 